\title{
ANALISIS PENGARUH PRODUK, PERSEPSI HARGA DAN KUALITAS PELAYANAN TERHADAP MINAT PEMBELIAN ULANG
}

\author{
Amirudin $^{1}$, Ignatius Soni Kurniawan ${ }^{2}$ \\ ${ }^{1,2}$ Fakultas Ekonomi Universitas Sarjanawiyata Tamansiswa \\ Jln. Jl. Kusumanegara No.157, Muja Muju, Umbulharjo, Kota Yogyakarta \\ E-mail : amirudinamir212@gmail.com \\ diterima: 8/12/2018; direvisi: 4/1/2019; diterbitkan: 31/3/2019
}

\begin{abstract}
The purpose of the research is to test the effect of product, perceived price, and services quality toward repurchase intention. Samples taken were 100 respondents using accidential sampling technique. Data analysis method using multiple linear regression test. This study found that service quality have a positive and significant effect on repurchase intention, while product and perceived price does not have a significant effect on repurchase intention.
\end{abstract}

Keywords: Products, Perceived Price, Services Quality, Repurchase Intention

\section{PENDAHULUAN}

Perilaku konsumen dapat diprediksi berdasarkan perilakunya di masa lampau. Perilaku konsumen dalam pembelian meliputi urutan kesadaran kebutuhan, mengumpulkan informasi produk, memilih, membeli, mengkonsumsi, dan perilaku paska pembelian (Schiffman dan Kanuk, 2010:7). Konsumen mendapat pengalaman melalui pembelian produk, konsumsi produk, dan evaluasi merek. Perilaku konsumen dimasa mendatang akan menyesuaikan dengan pengalaman dari masa lalunya.

Setelah konsumen melakukan pembelian produk atau jasa, apabila produk yang dikonsumsi dianggap cocok, intensi membeli lagi akan muncul. Minat pembelian ulang diwujudkan dengan kemauan individu membeli produk yang sama berulangkali (Setiadi, 2003:250), lebih lanjut bahkan dapat merekomendasikan kepada orang lain. Pembelian ulang ini adalah akibat dari kesan positif atas penggunaan produk (Hicks et al., 2005). Ingatan konsumen atas pengalaman konsumsi menentukan terjadinya pembelian ulang atau sebaliknya berpindah produk.

Produk merupakan hal utama bagi konsumen dalam membentuk kesan. Produk dituntut untuk sesempurna mungkin agar dapat melayani keinginan konsumen. Penelitian yang menguji pengaruh produk terhadap minat pembelian ulang dilakukan oleh Chinomona dan Maziriri (2017) sedangkan yang mengaitkan terhadap kesetiaan dilakukan oleh Pourdehghan (2015). Kegiatan penghantaran produk kepada konsumen juga membutuhkan kegiatan pelayanan. Semakin pelayanan dirasakan berkualitas oleh konsumen maka minat beli ulang juga akan muncul di benak konsumen.

Kualitas pelayanan menentukan puas atau kecewanya konsumen terhadap penghantaran produk oleh produsen. Pelayanan adalah bagian penting layanan perusahaan dalam memenuhi kebutuhan konsumen (Muslichati \& Warti, 2015). Apabila kualitas pelayanan yang didapatkan sama atau bahkan melebihi yang diinginkan, maka minat pembelian ulang akan meningkat, bahkan dapat meluas pada produk lain yang ditawarkan. 
Agar mampu memasarkan produk atau jasa sesuai dengan rencana, pemasar dituntut untuk cermat dalam menetapkan harga sesuai dengan target pasarnya. Harga adalah salah satu dimensi marketing mix yang bersifat fleksibel, yang mampu disesuaikan dalam waktu cepat (Tjiptono, 2008: 47). Harga dapat ditetapkan dengan cara melihat keadaan atau kondisi pasar, apabila harga jauh lebih tinggi maupun jauh lebih rendah dari pesaing maka konsumen akan membandingkan kualitas produk dengan layanannya. Terdapat anggapan umum bahwa harga merupakan gambaran kualitas suatu produk yang di tawarkan ke pasar, harga yang mahal menggambarkan produk yang berkualitas. Jiang (2005) meneliti pengaruh harga terhadap minat beli ulang, sedangkan Pourdehghan (2015) mengaitkannya terhadap kesetiaan. Penelitian ini ingin menguji robustness teori tersebut melalui studi kasus pada konsumen sebuah restoran di Yogyakarta.

\section{TINJAUAN PUSTAKA}

Suatu produk yang ditawarkan perusahaan dan dianggap mampu memuaskan keinginan konsumen akan berdampak pada minat pembelian ulang, sebaliknya ketidaksesuaian dengan harapan akan membuat konsumen beralih membeli produk dari perusahaan lain. Produk dinyatakan Kotler dan Keller (2012: 325) sebagai semua hal yang dapat ditawarkan guna memenuhi kebutuhan konsumen. Penelitian Chinomona dan Maziriri (2017) mengkonfirmasi pengaruh positif produk terhadap minat pembelian ulang.

$\mathrm{H} 1$ : produk berpengaruh positif terhadap minat pembelian ulang.

Harga dinyatakan Tjiptono, (2008:151) sebagai satuan moneter yang digunakan oleh konsumen untuk mendapatkan suatu hak atas produk.
Mahal atau murahnya harga dipersepsikan berbeda-beda oleh konsumen. Banyak faktor yang dapat mempengaruhi persepsi konsumen, antara lain dari pembelian di masa lalu, informasi dari iklan, informasi dari perusahaan sejenis, termasuk informasi dari media sosial yang digunakan. Mahal atau murahnya harga dibentuk dari persepsi konsumen atas pengorbanan untuk mendapatkan produk dibanding keterpenuhan kebutuhan atas produk (Zeithaml, 1988). Konsumen yang mempersepsikan harga sesuai dengan yang didapatkan saat mengonsumsi produk akan berminat membeli ulang. Jiang (2005) menyatakan adanya pengaruh persepsi harga pada minat pembelian ulang.

$\mathrm{H} 2$ : persepsi harga berpengaruh terhadap minat pembelian ulang.

Pelayanan merupakan sesuatu yang dapat memenui kebutuhan maupun harapan konsumen (Akbar \& Parvez, 2009). Pelayanan yang memberikan kenyamanan pada konsumen akan membentuk minat pembelian ulang pada konsumen dan bahkan membeli lebih banyak. Kualitas pelayanan meliputi bukti fisik, kehandalan, daya tanggap, jaminan, dan empati (Parasuraman et al., 1985). Penelitian Ebrahimi \& Tootoonkavan (2014), Saleem, et al. (2017), dan Mensah \& Mensah (2018) menyatakan adanya pengaruh positif kualitas pelayanan terhadap minat pembelian ulang.

H3: pelayanan berpengaruh positif terhadap minat pembelian ulang.

\section{METODE PENELITIAN}

Penelitian bersifat kuantitatif, dan pengambilan datanya menggunakan kuesioner skala likert. Populasi yang digunakan adalah konsumen Restoran AM di Yogyakarta (identitas restoran di rahasiakan) dengan jumlah tidak dapat diketahui. Jumlah anggota sampel tidak diketahui maka digunakan rumus berikut 
$n=\frac{\mathrm{z}^{2}}{4(m o e)^{2}} \quad$ (Widiyanto, 2008: 59), dengan hasil $96,4 \approx 97$ dan dibulatkan 100 responden. Pengambilan sampel mengunakan teknik accidental sampling pada konsumen yang sedang melakukan pembelian di lokasi restoran. Pengujian menggunakan regresi liner berganda dengan alat bantu program SPSS.

\section{HASIL DAN PEMBAHASAN}

Pengunjung restoran di dominasi oleh perempuan (53\%). Berdasar usia, mayoritas pengunjung berusia kurang dari 25 tahun (65\%) konsisten dengan status pekerjaan sebagai pelajar atau mahasiswa (65\%), hal ini relevan karena lokasi restoran yang dekat dengan lingkungan kampus. Berdasar tingkat pendidikan, responden didominasi oleh lulusan SMA (42\%), sedangkan berdasar penghasilan, mayoritas responden berpenghasilan dibawah $\mathrm{Rp} 3$ juta (72\%), meskipun restoran didominasi mahasiswa, terdapat 8\% kelompok konsumen berpenghasilan Rp 5.000.001 s.d. Rp 10.000.000 dan 3\% diatas $\mathrm{Rp}$ 10.000 .000 yang juga mengunjungi restoran tersebut. Berdasar status tempat tinggal sekarang, $88 \%$ berasal dari Daerah Istimewa Yogyakarta (DIY) sisanya dari luar DIY (12\%).

Ringkasan uji kualitas data pada tabel 2 menunjukkan validitas semua item variabel terpenuhi karena nilai Pearson Correlation memiliki $p$ (sig. 1 tailed) $<0,05$. Nilai cronbach's alpha based on standardized items untuk produk $(0,626)$, persepsi harga $(0,708)$, kualitas pelayanan $(0,748)$ dan minat pembelian ulang $(0,802)>0,6$ yang artinya semua variabel adalah reliabel.

Interval dengan penilaian 5 skala ditentukan sebagai berikut.

Sehingga dapat ditentukan range jawaban sebagai berikut.
Skor rata-rata antara $1,00-1,80$ : Sangat Tidak Baik

Skor rata-rata antara 1,81 - 2,60 : Tidak Baik

Skor rata-rata antara 2,61 - 3,40 : Cukup Baik

Skor rata-rata antara 3,41 - 4,20 : Baik

Skor rata-rata antara 4,21 - 5,00 : Sangat Baik

Statistik deskriptif menunjukkan nilai mean tertinggi pada variabel produk terjadi pada indikator penampilan 1 dan nilai mean terendahnya pada indikator selera 1. Pada variabel persepsi harga mean tertinggi terjadi pada indikator kesesuaian harga dengan kualitas 1 dan mean terendah terjadi pada indikator harga bersaing 2. Mean tertinggi pada variabel kualitas pelayanan terjadi pada kehandalan 1 dan mean terendahnya terjadi pada bukti fisik 1. Mean tertinggi pada variabel minat pembelian ulang terjadi pada minat eksploratif 2 dan mean terendahnya terjadi pada transaksional 2 dan minat referensial 1.

Hasil pengujian asumsi klasik (Tabel 4) menunjukkan semua variabel bebas memiliki nilai Tolerance $>0,10$ dan nilai $V I F<10$ yang artinya pada model regresi tidak terjadi multikolonieritas. Hasil Spearman's rho test menunjukkan nilai $p>0,05$ atau tidak signifikan, yang artinya model regresi tidak terjadi heteroskedastisitas. Nilai KolmogrovSmirnov $Z$ sebesar 0,775 dan nilai Asymp. Sig. (2-tailed) sebesar 0,585 >0,05, atau tidak signifikan, yang artinya data residual terdistribusi normal.

Berdasarkan hasil uji t, diketahui bahwa nilai $t$ dari variabel produk memiliki $p 0.484 / 2$ yaitu $0,242>0,05$ atau tidak signifikan, hipotesis 1 yang menyatakan produk berpengaruh positif terhadap minat pembelian ulang, ditolak. Statistik deskriptif pada tabel 3 menunjukkan item produk dinilai pada rentang rata-rata $3,30-4,11$, masih terdapat jawaban "sangat tidak setuju" 
pada indikator penampilan dan selera. Jawaban "tidak setuju" dapat ditemukan pada semua indikator (penampilan; selera; rasa; tekstur). Nampak bahwa konsumen menilai produk belum maksimal, masih ada masalah pada produk yang perlu dicari, misal dari aroma produk, konsistensi penyajian produk, dan kesesuaian gambar pada menu produk atau iklan di media promosi dengan realitanya. Temuan ini tidak mendukung Chinomona dan Maziriri (2017) yang menyatakan bahwa produk berpengaruh positif terhadap minat pembelian ulang.

Pengujian nilai $\mathrm{t}$ pada Tabel 5 menunjukkan variabel persepsi harga memiliki $p 0,892>0,05$ atau tidak signifikan, hipotesis 2 yang menyatakan persepsi harga berpengaruh terhadap minat pembelian ulang, ditolak. Statistik deskriptif pada Tabel 3 menunjukkan indikator kesesuaian harga masih ada yang dijawab "sangat tidak setuju". Sedangkan jawaban "tidak setuju" masih dapat ditemukan pada semua indikator persepsi harga (kesesuaian harga dengan kualitas produk; kesesuaian harga dengan manfaat; harga bersaing). Temuan bahwa variabel persepsi harga dan variabel produk yang tidak berpengaruh terhadap minat pembelian ulang menunjukkan adanya keterkaitan. Nampak bahwa produk dan harga yang ditawarkan oleh Restoran AM perlu dikaji kesesuaiannya. Dari hasil karakteristik responden (Tabel 1), pelanggan restoran didominasi oleh pelajar/mahasiswa, dengan usia $<25$ tahun, dan tingkat penghasilan dibawah $\mathrm{Rp}$ 3.000.000, oleh karenanya restoran perlu mengkaji apakah harga yang ditawarkan pada saat ini sesuai dengan pelanggan yang disasarnya. Restoran perlu memperjelas segmen ekonomi pelanggan yang disasarnya, hal ini karena ditemukan $25 \%$ pelanggan yang berpenghasilan $\mathrm{Rp} 3.000 .000-\mathrm{Rp}$
10.000.000, dan 3\% diatas Rp 10.000.000. (Penelitian ini konsisten dengan temuan riset $\mathrm{Xu}$, et al., (2016) yang menyatakan persepsi harga tidak berpengaruh positif dan signifikan terhadap minat beli ulang.

Berdasarkan hasil uji t, diketahui bahwa nilai $\mathrm{t}$ dari kualitas pelayanan memiliki $p 0,000 / 2$ yaitu $0,000<0,05$ yang menunjukkan ada pengaruh signifikan dari kualitas layanan terhadap minat pembelian ulang. Nilai beta yang positif $(5,232)$ menunjukkan arah pengaruh adalah positif, hipotesis 1 yang menyatakan kualitas pelayanan berpengaruh positif terhadap minat pembelian ulang diterima. Hasil statistik deskriptif pada Tabel 3 menunjukkan tidak ada indikator kualitas pelayanan yang dijawab "sangat tidak setuju", sedangkan jawaban "tidak setuju" hanya terjadi pada indikator bukti fisik, yang menunjukkan bahwa kualitas layanan yang diberikan sesuai dengan harapan konsumen. Temuan ini sesuai dengan Ebrahimi \& Tootoonkavan (2014), Saleem et al., (2017), dan Mensah \& Mensah (2018) bahwa semakin layanan berkualitas maka semakin minat beli ulang meningkat

\section{KESIMPULAN DAN SARAN}

Penelitian bertujuan menguji pengaruh produk, persepsi harga dan kualitas pelayanan terhadap minat pembelian ulang pada Restoran AM Yogyakarta. Temuan menunjukkan adanya pengaruh positif kualitas pelayanan terhadap minat pembelian ulang di Restoran AM Yogyakarta. Oleh karenanya pimpinan restoran perlu mempertahankan dan meningkatkan kinerja kualitas layanannya melalui bukti fisik, kehandalan, daya tanggap, jaminan, dan empati agar minat pembelian ulang konsumen dapat dipertahankan.

Penelitian ini gagal membuktikan pengaruh produk dan persepsi harga terhadap minat pembelian ulang. Implikasi praktis dari temuan ini adalah restoran perlu mempertimbangkan kembali produk 
yang ditawarkan apakah sudah sesuai dengan harapan konsumennya. Restoran juga perlu mempertimbangkan kesesuaian harga yang ditawarkan dengan mayoritas segmen ekonomi konsumennya. Penelitian selanjutnya perlu mempertimbangkan variabel lain seperti lokasi, promosi, loyalty, dan kepuasan untuk memprediksi minat beli ulang konsumen.

\section{DAFTAR PUSTAKA}

Akbar, M. M. \& Parvez, N. (2009). Impact of survice Quality, Trust, and Customer Satisfaction Loyalty,. ABAC Journal, 29(1), 24-38

Bennion, M., \& Scheule, B. 2004. Introductory foods (12th edition). USA: Pearsonprentice Hall.

Chinomona R. \& Maziriri, E. T. 2017. The influence of brand awareness, brand association and product quality on brand loyalty and repurchase intention: a case of male consumers for cosmetic brands in South Africa. Journal of Business and Retail Management Research (JBRMR), 12(1): 143-154

Ebrahimi, M. R. \& Tootoonkavan, S. 2014. Investigating the Effect of Perceived Service Quality, Perceived Value, Brand Image, Trust, Customer Satisfaction on Repurchase Intention and Recommendation to Other. European Journal of Business and Management, 6(34): 181186.

Hicks, J.M., Page Jr., T. J., Behe, B. K., Dennis, J. H., Fernandez, R. \& Thomas. (2005). Delighted Consumers Buy Again", ",
Journal of Consumer Satisfaction, Dissatisfaction and Complaining Behaviour, 94-104.

Jiang, Pingjun. 2005. Customer intention to return online: price perception, attribute-level performance, and satisfaction unfolding over time. European Journal of Marketing, 39(1/2):150-174.

Kotler, P. dan Keller, K. L. 2012. Marketing Management. Edisi 14. Global Edition. Pearson Prentice Hall.

Mensah, I. \& Mensah, R. D. 2018. Effects of Service Quality and Customer Satisfaction on Repurchase Intention in Restaurants on University of Cape Coast Campus. Journal of Tourism, Heritage \& Services Marketing, 4(1): 27-36.

Muslichati, E. Z \& Wartini. (2015). Pengaruh Kualitas Layanan dan Inovasi Layanan terhadap Kepuasan Konsumen pada Rumah Sakit Buah Hati Kudus. Management Analysis Journal, 4(4), 341-347.

Parasuraman, Valarie A. Zeithaml, \& Leonard L. Berry. (1985). A Conceptual Model of Service Quality and Its Implications for Future Research. The Journal of Marketing, 49, 41-50.

Pourdehghan, A. 2015. The impact of marketing mix elements on brand loyalty: A case study of mobile phone industry. Marketing and Branding Research, 2(2015): 4463.

Saleem, M. A. Zahra, S., \& Yaseen, A. 2017. Impact of service quality and 
trust on repurchase intentions the case of Pakistan airline industry, Asia Pacific Journal of Marketing and Logistics, 29(5): 1136-1159.

Schiffman, L. G. \& L. L Kanuk. (2010). Consumer Behaviour. 10th ed. New Jersey: Prentice Hall., 2010.

Setiadi, N, J. (2003). Perilaku Konsumen: Konsep dan Implikasi untuk Strategi dan Penelitian Pemasaran, (Perilaku Konsumen).

Stanton, Wiliam J. 1998. Prinsip Pemasaran Edisi Ketujuh, Jilid 1. Jakarta: Erlangga.

Tjiptono, F. 2008. Strategi Pemasaran. Yogyakarta: Andi Offset.
Widiyanto, I. 2008. Pointers metodologi penelitian. Semarang: CV Dikalia.

Xu, J. X. Ahmad, M. I. \& Ali, R. 2016. Factors Influencing the Customers Repurchase Decisions. American Journal of Social and Management Sciences, 7(1): 24-32.

Zeithaml, V. A. (1988). Customer perceptions of price, quality and value. Journal of Marketing, 52. 